\title{
Morphological and ecological studies of two chelonian reptiles
}

\author{
Suzan A.A. Naguib; Ragaa M. El-Deeb and Fatma K. Abd El- Haddy \\ Department of Zoology, Faculty of Science, Ain Shams University, Cairo, Egypt.
}

\section{ABSTRACT}

The present investigation aims to illustrate the morphological and ecological differences of tortoises and terrapins. Two types of chelonian reptiles were selected; the herbivorous land tortoise, Testudo graeca terrestris and the freshwater terrapin, Pseudemys scripta elegans. Testuda graeca terrestris is highly adapted to live on land since it can live for a long period without water on sand dunes and semidesert areas during warm days. It is characterized with a dome shell and stumpy legs. All tortoises are vegetarians that fed on lettuce. On the other hand, the freshwater terrapin; Pseudemys scripta elegans is known to inhabit the Mississippi valley. It is semiaquatic reptile, known as red eared terrapin, spends in fresh water as much time as it spends on land. Pseudemys scripta elegans may by kept as pet with few hazards as it may cause Salmonellasis. This species is omnivorous since they feed on fishes, frogs, flesh, snails, worms and numerous aquatic plant species.

Keywords: Chelonian reptiles, feeding habits, hibernation period and nesting behavior

\section{INTRODUCTION}

The first order of living Reptiles is that of the Chelonia which appeared about 200 million years ago during the late Triassic. Gans, (1970) stated that there are approx. 294 species of chelonians alive today.

Bellairs (1968) described the shell of all members of order Chelonia as a hard box made up of scutes (bony plates) that can form a hard or soft shell. This shell consists of two parts: the top dorsal carapace and the ventral plastron.

Capulla (1990) stated that the concentric rings formed on the epidermal scutes of the carapace determine the age of the reptile.

Hanafy and Sallam (2003) stated that chelonian reptiles have heart with threechambers and the interventricular septum being imperfect. Moreover, Miller (2004) stated that the lungs of chelonian reptiles are voluminous and respiration is by swallowing air, as in the frogs.

Al-Merghani et al. (2000) stated that turtles do not have teeth, instead they possess a sharp beak that enables them to tear their food. All will pass prolonged periods without food especially during hibernation period.

Parker and Haswell (1966) mentioned that the ribs of all chelonian reptiles are greatly expanded and are united to one another by sutures, therefore the walls of the thoracic cavity are immovable.

Hughes (1974) indicated that all the bones of the skull of chelonians except the lower jaw and the hyoid bone are immovably united together.

Richter and Jacob (1988) illustrated that land tortoises are herbivores; feeding on grazing grasses, weeds, leafy greens, flowers, lettuce and some fruits, while Dodd and Kennentt (2002) stated that green sea turtles are omnivorous, eating seaweeds, algae, jellyfishes, comb jellies, crabs, mollusks, crustaceans and fishes. On the other hand, Tanner and Avery (1982) stated that the red-eared terrapins are omnivorous, eating fishes, tadpoles, snails, mealworms and aquatic insects. 
Van Dijk (2010) indicated that most chelonian reptile, hibernate in winter from May to October every year to avoid cold conditions and dehydration. Alderton (1988) stated that female tortoise lays about 1-25 eggs-that are incubated underground for 100 days.

Van de Merwe et al. (2005) mentioned that the female turtle lays from 50-200 eggs distributed on 3-8 nests which they drags up the beach.

Fritz and Peter (2007) stated that the freshwater female terrapin may lay from 2 to 30 eggs in about five clutches-every year.

The present study aims to illustrate comparative ecological and morphological studies of a herbivorous, Testudo graeca terrestris and an omnivorous Pseudemys scripta elegans.

\section{MATERIALS AND METHODS}

\section{Examined animals:}

Specimens of Testudo graeca terrestris were obtained from El-Salum near the libyan desert and Pseudemys scripta elegans was imported from its original home agencies dealing with tame animals. Such agencies were the source for the specimens needed for the present study.

The first species was selected for the present study as a herbivorous land tortoise. All tortoises are vegetarians (Ritcher and Jacob, 1988). Their total length were ranging between $5-14 \mathrm{~cm}$ (Fig. 1) examined in the present study.

On the other hand, the second species is a semiaquatic terrapin, known as red eared terrapin. As this species is omnivorous (Hamlyn, 1989) since they feed on small fishes, frogs \& flesh. Their total length varied from 5 to $28 \mathrm{~cm}$ (Fig. 2).

\section{RESULTS}

\section{DISTINCTIVE FEATURES OF SPECIES}

\section{1- Testudo graeca terrestris (the Greece land tortoise)}

The head of this species is triangular in shape and dorsoventrally flattened and its top entirely covered with shields. The head is yellowish or dusty in colour. It has a long flexible neck. Even the head, limbs and tail can be more or less completely withdrawn into the shell for safety. The mouth is large, but instead of teeth, horny plates form the margin of the jaws that are used to crush their food. The mouth has an upper fixed jaw and a lower movable one. The snout is short and strongly projecting beyond the lower jaw. The external nares are placed together, near the anterior end of the snout. The eyes are situated one on each side of the head, are each guarded by three eyelids; a short, thick, opaque upper eyelid; a longer, thin lower lid and a transparent nictitating membrane, which moves over the eyeball from the anterior corner of the eye. Behind the angle of the jaw on either side, there is a thin tympanic membrane (Fig. 1).

Over the exposed parts of the body, the skin is thick, tough, much wrinkled and scaly. The limbs are covered by strong bony scales .The fore-limb is provided with five digits, while the hind-limb is provided with only four toes. The hind-limbs are stumpy, elephant-like, cylindrical and toes are not webbed. Most digits are provided with large horny claws which are used in climbing, crawling and digging. The Tortoise is distinguished from all other animals by its exoskeleton or shell which is broad and protects the vital organs. This shell or the bony box consists of a convex dorsal armour, the carapace, and a flattened ventral armour, the plastron. Both 
carapace and plastron are usually covered by a number of symmetrically arranged horny plates called scutes or shields (Fig. 1).

The convex dorsal carapace consists of a series of median plates, right and left series of costal plates surrounded by a series of marginal plates. The median series consist of a small anterior nuchal plate followed by five vertebral or neural plates and end by a large pygal plate. There are usually four costal plates on each side, they are firmly united by their inner and outer extremities with the neural and marginal plates respectively. Finally, there are eleven marginal bony plates on each side. The colour of the carapace is yellowish or pale greyish yellow. Their plates are more or less margined with brown or blackish colour restricted chiefly to the anterior of the vertebral (neural) plates, while in the costals this brown or blackish colour is restricted to their anterior and external lateral margins and is recorded by the concentric rings formed on the epidermal scutes of the carapace as each is enlarged as its margin (Fig. 1).

\section{2-Pseudemys scripta elegans (the red-eared terrapin)}

The jaws lack teeth and instead are clothed with hard horny beak which is sharp and can inflict considerable damage. The upper jaw is high, strong and not notched or weakly serrated. The large eyes have upper and lower eyelids and a nictitating membrane located in the corner of the eye. Just behind the angle of the jaws is seen the circular eardrum flush with the surface, as in frogs. In addition, there is a broad elongated red stripe behind the eyes, near the eardrum; hence its common name. The head is followed by a long, strong and flexible neck. Numerous long yellow stripes, on sides of the neck, and behind the eyes continue with the lower jaw. The head is grayish or dark olive in colour on its upper surface. The limbs are strong, muscular and covered by small horny scales. They have a dark grayish-olive colour with yellow stripes. The hind limbs with paddle-like webbed swimming feet, having horny claws. The hind-limb is provided with five digits with much elongated claws that are useful in crawling or digging.

The most unique feature of terrapins is their shell which is poorly ossified, broad, smooth, flattened and protects the internal organs. The shell is composed of bony plates covered by horny shields. The shell consists of a dorsal arched carapace, a ventral flat plastron and lateral bridges connecting carapace and plastron; known as marginal or intramarginal plates. The carapace is slightly keeled with flared serrate posterior edge. It includes five rows of bony plates. A median row consists of an anterior nuchal plate followed by five vertebral or neural plates and ends by a large pygal plate. On either side of the median row, there are two rows of bony plates namely costals and marginals. Each costal row consists of four bony plates. Finally, the marginal row consists of eleven bony plates on each side of the carapace. The carapace is grayish-olive to grayish-black in colour with variable patterns of small round yellow spots with large black markings.

The flattened ventral plastron is composed of twelve scutes arranged in six pairs which are; gular, humeral, pectoral, abdominal, femoral and anal plates from anterior to the posterior end. In addition, there are about five small scutes that form part of a bridge with the carapace and contact marginals giving the shape of boat to the turtle's shell to suit the swimming habits of this species. These are named as the inguinal or the infra-marginal plates. The colour of the plastron is yellowish to white with large black blotches. With age, the colour of the plastron changes into the black colour. Terrapins are noted for their relatively slow growth and long lives. Growth of species is recorded by the concentric rings formed on the epidermal scutes of the carapace as each is enlarged as its margin. 


\section{FEEDING HABITS}

\section{1- Testudo graeca terrestris}

Most land based tortoises are herbivores; feeding on grazing grasses, weeds, leafy greens, flowers, lettuce and some fruits although there are some omnivorous species in this family. Pet tortoises typically require a diet based on wild grasses, weeds, leafy greens and certain flowers. Certain species consume worms or insects and carrion in their normal habitat. Too much protein is detrimental to herbivorous species and has been associated with shell deformities and other medical problems. As different tortoise species vary greatly in their nutritional requirements, it is essential to thoroughly research the dietary needs of an individual tortoise.

\section{2- Pseudemgs scripta elegans}

Red-eared sliders are omnivorous and eat a variety of animals and plant materials in the wild, including but not limited to fish, crayfish, carrion, tadpoles, snails, crickets, mealworms, wax worms, aquatic insects and numerous aquatic plant species. The captive diet for pet red-eared sliders should be a varied diet, consisting of invertebrates such as worms, aquatic and land plants, and other natural foods. A nutritious food readily accepted by young terrapins is baby clams soaked in krill oil covered with powdered coral calcium. Younger terrapins tend to be more omnivorous (to obtain more animal protein) than adults.

\section{HIBERNATION PERIOD}

\section{1- Testudo graeca terrestris}

Hibernation is a nature's mechanism to protect its cold-blooded creatures (and some warm-blooded animals as well) in cold weather or when food and water are scarce. Most tortoises of the types most commonly kept as pets do actually hibernate in the wild. They do so, however, for much shorter periods than they are frequently subjected to captive collections. It has been common place to attempt a hibernation of up to six or even seven months, whereas in the wild, these tortoises have been used to hibernation rarely longer than ten to twelve weeks. We believe in replicating natural conditions as closely as possible in respect of hibernation periods, and so we do not recommend giving that tortoise an over-long hibernation. Most fatalities occur either near the beginning, or at the end of the hibernation period. The reasons for some of these fatalities can be discussed in detail later, but such tortoise's chances can be improved simply by limiting the period of hibernation to not more than 20 weeks at the outside. Thus, it should be stressed, for a perfectly fit specimen which is fully up to weight. Tortoises which are anything less than $100 \%$ fit, or are in any way underweight, require a proportionally shorter period of hibernation under carefully controlled conditions; possibly they may even need to be kept awake and feeding over the entire winter season.

In order to survive hibernation in good condition, tortoises need to have built up sufficient reserves of fat bodies; thus in turn stores vitamins and water. Without fat, vitamins and water tortoises die off starvation or dehydration. Adequate reserves of body fat are vital to tortoises in hibernation. They live off these reserves, and if the reserves run out too soon then the animal's body will begin to use up the fat contained within the muscles and internal organs, eventually these too will become exhausted.

\section{2- Pseudemys scripta elegans}

Pseudemys scripta elegans do not hibernate, but actually they brumate, becoming less active, but occasionally rising for food or air. Brumation can occur in varying degrees. Red-eared sliders brumate over the winter at the bottom of ponds or shallow lakes. They become inactive generally, in October, when temperatures fall below $10^{\circ} \mathrm{C}\left(50^{\circ} \mathrm{F}\right)$. Individuals usually brumate under water. They have also been 
found under banks and hollow stumps and rocks. In warmer winter climates, they can become active and come to the surface for basking. When the temperature begins to drop again, however, they quickly return to a brumation state. Sliders will generally come up for food in early March to as late as the end of April. Red-eared sliders kept captive indoors do not brumate. To prevent attempted brumation in an aquarium, lights should be on for 12-14 hours per day and the water temperature should be maintained between 24 and $27^{\circ} \mathrm{C}$ ( 75 and $81^{\circ} \mathrm{F}$ ). Water temperatures must be under $13^{\circ} \mathrm{C}\left(55^{\circ} \mathrm{F}\right)$ for aquatic terrapins to brumate properly. Controlling temperature changes to simulate natural seasonal fluctuations encourages mating behaviour.

\section{SEXUAL DIMORPHISM}

\section{1- Testudo graeca terrestris}

Many species of tortoises are sexually dimorphic, though the differences between males and females vary from species to species. In some species, males have a longer, more protruding neck plate than their female counterparts, while in others the claws are longer in males than females. In most tortoise species, the female tends to be larger than the male. The male also has a plastron that is curved inwards to aid reproduction. The easiest way to determine the sex of a tortoise is to look at the tail. The females, as a general rule have a smaller tail which is dropped down, whereas the males have a much longer tail which is usually pulled up to the side of the shell. Males have concave plastron that is more or less keys with the convex carapaces of females during mating

\section{2- Pseudemys scripta elegans}

Male and female terrapins may be distinguished in a number of ways. Males usually have longer tails, elongated fore-limb claws and a concave plastron that is more or less keys with the convex carapace of the female during mating. Females are usually larger and bulkier than males. The cloacal opening is rounded in shape and is borne on the ventral side of the base of the tail. The female red-eared slider grows to be $25-33 \mathrm{~cm}$ (10-13 in) in length and males $20-25 \mathrm{~cm}$ (8-10 in).

Claws are elongated in males to allow a better grip on the carapace of females during mating. Typically, the cloacal opening of the female is or under the rear edge of the carapace, while the male's opening occurs beyond the edge of the carapace. Older males can sometimes have a melanistic coloration, being a dark grayish-olive green, with markings being very subdued. The red stripe on the sides of the head may be difficult to see or be absent.

\section{BREEDING AND REPRODUCTION}

\section{1- Testudo graeca terrestris}

Sexual reproduction involves courtship rituals between the male and the female tortoises. During the mating season, between April and November, females lay their eggs in the open areas; about 1-25 eggs that incubate underground for 100 days. The sex of the eggs is determined by the temperature, where they are incubated in a nest laid below sand. If the sand is over 30 degrees Celsius, it's a female and if below 30 degrees Celsius, the egg is a male. Gopher tortoises can live more than 40 years. The gopher tortoise reaches maturity at about 10-15 years of age, when their shells are around 9 inches $(23 \mathrm{~cm})$ long. They may mate from February through September, with a peak throughout May and June. Females may lay clutches of 3-14 eggs, depending on body size, in a sandy mound very close to the entrance of their burrow. Ninety percent of clutches may be destroyed by predators such as armadillos, raccoons, foxes, skunks and alligators before the eggs hatch, and less than $6 \%$ of eggs are expected to grow into tortoises that live one year or more after hatching. 


\section{2 - Pseudemys scripta elegans}

Courtship and mating activities for red-eared sliders usually occur between March and July, and take place under water. The male swims toward the female and flutters or vibrates the back side of his long claws on and around her face and head. The female swims toward the male and, if she is receptive, sinks to the bottom for mating. If the female is not receptive, she may become aggressive towards the male. The courtship can take up to 45 minutes, but the mating itself usually takes only 10 to 15 minutes. Sometimes a male will appear to be courting another male. This is actually a sign of dominance, and they may begin to fight. Juveniles may display the courtship dance, but until the terrapins are 5 years of age, they are not mature and are unable to mate. After mating, the female spends extra time basking to keep her eggs warm. She may also have a change of diet, eating only certain foods or not eating as much as she normally would. Mating begins in May and egg-laying occurs in May through early July. A female might lay from 2 to 30 eggs, with larger females having larger clutches. One female can lay up to 5 clutches in the same year, and clutches are usually spaced 12 to 36 days apart. The time between mating and egg laying can be days or weeks. Eggs hatch 60 to 90 days after they have been laid. Late season hatchlings may spend the winter in the nest and emerge when the weather warms in the spring. Just prior to hatching, the egg contains $50 \%$ terrapin and $50 \%$ egg sac. A new hatchling breaks open its eggs with its egg-tooth, which falls out about an hour after hatching. This egg tooth never grows back. Hatchlings may stay inside their eggshells after hatching for the first day or two. When a hatchling decides to leave the shell, it has a small sac protruding from its plastron. The yolk sac is vital and provides nourishment while visible and several days after it has been absorbed into the terrapins belly.

\section{DISCUSSION}

The present investigation was proposed to study in a comparative manner, the ecological and morphological studies of two chelonian reptiles, a herbivorous land tortoise; Testudo graeca terrestris and an omnivorous freshwater terrapin; Pseudemys scripta elegans.

The available literature indicates that the most unique feature of both species is their shell which is ossified, broad \& flattered to protect the internal organs. The shell is composed of bony plates covered by horny shields. It consists of a dorsal arched carapace and a ventral flat plastron. This agrees with the description of Nath (1967), Orr (1971) and Luppa (1977) in case of chelonian reptiles. The mouth opening of Testudo graeca terrestris is small and jaws not strong encased with large horny plates that function as teeth. In contrast, the mouth opening in Pseudemys scripta elegans is very large and has no teeth and instead the jaws are clothed with hard horny sharp beak. Similar observations have been recorded by Boolootian (1979) and Emst and Altenbourf (1997).

The tongue of Testudo graeca is short, broad and much more limited in its movement where as in Pseudemys the tongue is non protrusible, triangle in shape short, thick and biforked posterior, a condition similar to that described by Halliday (2002) in the turtle; Chelydra serpentina and Miller and Lagios (1970) in the common Nile turtle; Trionymx triunguis. There is a varition in the feeding habits of the two reptile. A fact accepted by Parker and Haswell (1966) in Lacerta. Thus, tortoises feeding largely on vegetable food while Pseudemys is omnivorous feeding on fishes, 
snails, worms and aquatic-insects. A similar feeding habits have been described by Abo- Taira et al. (1988) in Natrix tessellata and Naguib (1988) in Testudo leithii.

Male and female tortoises and terrapins may be distinguished in a number of ways. Males usually have longer tails, elongated fore limb claws and a concave plastron that more or less keys with the convex carapace of the females during mating. Females are usually larger and bulkier than males. Their cloacal openings are rounded in shape and is borne on the ventral side of the base of the tail while the male's opening occurs beyond the edge of the carapace. Claws are elongated in males to allow a better grip on the carapace of female during mating. These findings in agree with Young (1950), Naguib (1988) and Alderton (1988).

Although the factors driving of a nest site on a specific beach are not well for freshwater terrapins (Motimer 1990 \& Miller et al. 2003), several factors may be influential in the choice of an optimal nesting site, e.g high humidity and well ventilated (Miller, 1997). There should be sussicient space above the high tide line for nesting to take place and for clutch shading (Van de Merwe et al., 2005).

However, persistence of a nesting site depends on the successful production of hatchlings that re-nest at the same site, so the success of a particular nesting beach is only revealed after a period of many years (Frazier et al., 1987). Counting the number of clutched laid per season is the most common technique to assess population size and trends (Schroeder and Murphy, 1999). At the present work, the densities of nesting varied between sites and years (Hughes, 1974).

Surveying a certain beach at the beginning of the nesting season for few days is expected to count lower number of nests than surveying the same beach at the middle or end of the nesting season. Pollution is well documented as a major problem on many river terrapin nesting beaches by discouraging females from nesting (Witherington, 1992), altering nesting pattern (Salmon et al. 2000) and disturbing hatchling orientation (Witherington, 2000).

Frazier and Salas (1984) and Frazier et al. (1987) reported that less than 8 nests for the red eared terrapin along the nesting coasts beaches. The nesting beaches are the only practical place to determine terrapin population size in certain area. Since terrapin nesting females lay eight clutches pen season as well as Carr et al. (1978) stated that the total population of terrapin is three times the number of nested female.

The count of true nest varied greatly and significantly between years and the time and period of survey of coast to the resting season. This is in agree with Bojorndal and Donnelly (2000) and Groombridge and Luxmoore (1989). Survey of coast allow counting and more true nests with years. The mean clutch size of terrapin is varied between nesting beaches coasts and found to be ranged between 88 \& 160 eggs/ clutch. The stress of light pollution on females during laying their eggs could reduce the clutch sizes. The number of eggs per clutch averaged 1-25 eggs per clutch given by Diamond (1976).

In conclusion, specific precautions must be implemented to conserve these beaches, such as: excluding nesting beaches from the costal development process, reducing light intensity and beach uses; at least during the nesting season \& raising local community conservation of these terrapins and strengthening law enforcement process.

Fortunately, all of the valuable off shore nesting beaches are located within declared marine protected areas. This study created some sort of stability, continuity and monitoring coverage for almost 8 resting seasons. It contributed to future complete baseline for terrapins breeding populations trend in the rivers. 


\section{REFERENCES}

Abo-Taira, A. M.; Mansour, A. B.; Amer, M. A. and Zaher, M. M. (1988). Anatomical and histological studies on the alimentary tract of the lacertid lizard; Acanthodactylus boskianus (Family: lacertidae). Proc. Egypt. Acad. Sci., 38: 87-101.

Alderton, D. (1988). Turtles and Tortoises of the World. London: Bland ford press.

Al-Merghani, M.; Miller, J.D; Pilcher; N. J. and Al-Mansi, A. (2000). The green and hawksbill turtles in the kingdom of Saudi Arabia: Synopsis of nesting studies (1986-1997). Fauna of Arabia, 18: 369-384.

Bellairs, A. D. (1968). Reptiles, $2^{\text {nd }}$ edition, Hutchinson and Co. Ltd., London.

Bojorndal, F. A. and Donnelly M. (2000). Research and Management Techniques for the conservation of sea turtles. IUCN/SSC Marine Turtle Specials Group Publication No.4.

Boolootian, R.A. (1979). Zoology: An introduction to study of animals. Macmllian Publishing Co. Inc. New York and London.

Capula, M. (1990). The Macdonald Encylopedia of Amphibians and Reptiles London: Macdonald and Coltd.

Dodd, J. and Kenneth, R. (2002). North American Box turtles: A Natural history. University of Oklahoma press. ISBN 978.

Emst, C. H; Altenbourgh, R.G. and Mand Barbour, R.W. (1997). "Turtles of the world". Netherlands: ETI Information systems Ltd.

Frazier, J. and Salas, S. (1984). The status of marine turtles in the Egyptian Red Sea. Biol. conserv., 30: 41-47.

Frazier, J.; Bertram, G.C. and Peter, E.G. (1987). Turtles and marine mammals.pp.288-314. In: Key Environments: Red Sea. Pergamon press, Oxford.

Fritz, U and Peter, H. (2007). "Checklist of Chelonians of the World". Vertebrate Zoology., 57 (2): 149-368.

Gans, C. (1970). Biology of the reptilia. vol. $\underline{3}$ Morphology C. Academic press In. C. (London) LTD and New York.

Groombridge, B. and Luxmoore, R. (1989). The green turtle and hawksbill (Reptilia: cheloniidae): World status, exploitation and trade. Lausanne, Switzerland: CITE Secretariat, pp.601.

Halliday T. A. (2002). The New Encyclopedia of Reptiles and Amphibians. Oxford: Oxford University press.

Hanafy, M.H. and Sallam, A. (2003). Status of marine turtles nesting on the Egyptian beaches of the Red Sea. National Report to PERSGA, pp.45.

Hughes, G.R. (1974). The sea turtles of Southeast Africa.1.Status, Morphology and Distribution. Oceanographic Research Institute Investigational Report, Durban, 35: 1-144.

Kennett, R. and Cheristian, K. (1994). Physiological Zoology. vol. 67, No 5, pp.10871102. The university of Chicago press.

Luppa, H. (1977). "Biology of the Reptilia"., 6:225-213. Academic press, London.

Miller, J. D. (2004). Report on marine turtles of Wadi El-Gemal-Hamata Park, Report to the Red sea Protectorate Authority. Hurghada, Egypt.

Miller, M. R. and Lagios M. D. (1970). Biology of the reptilia. vol. $\underline{3}$, Academic press London and New York. 
Naguib, S. A. (1988). Comparative anatomical and histological studies of the digestive system of Testudo leithii and Eumeces schneiderii. M.Sc. Thesis, Faculty of Science, Zoology department. Ain Shams University.

Nath, V. (1967). A Text Book of Zoology. vol. 2(Chordata) S. Chand and Co., Delhi.

Orr, R.T. (1971). Vertebrate biology. W.B. Saunders company, Philadelphia, London, Toronto.

Parker, T.J. and Haswell, W.A. (1966). A text book of Zoology, vol.2, Macmillan, London.

Richter, K. and Jacob, U. (1988). The completely illustrated Atlas of Reptiles and Amphibia. New York, London, Toronto.

Roberts, M. F. (1982). Turtles. T.F.H. Publications, Inc. LTD.

Schroeder, B. and Murphy, S. (1999). Population surveys on nesting beaches. Research and Management Techniques for Conservation of Sea Turtles. IUCN/SSC Marine Turtle Specialist Group Publication No. 4.

Storrer, T. I. and Usinger, R. L. (1965). General Zoology. Mc Graw-Hill book company, New York. st. Louis. San Francisco-Toronto-London-Sydney.

Tanner, W. W. and Avery, D. F. (1982). Buccal Floor of Reptiles. Great Basin Nat., 42 (3): 273-349.

Van de Merwe J.; Ibrahim, K. and Whittier, J. (2005). Effects of hatchery shading and nest debth on the development and quality of Chelonia mydas hatchery management in Peninsular, Malaysia. Aust. J. Zool., 53: 205-211.

Van Dijk, P. P. (2010). "Terrapene carolina". IUCN List of Threatend species. International union for conservation of Nature.

Witherington, B. E. (2000). Behavioural responses of nesting sea turtles to artificial lighting. Herpetologica., 48: 31-39.

Young, J. Z. (1950). The life of Vertebrates. Oxford uni. press. $2^{\text {nd }}$ ed. London. New York. 


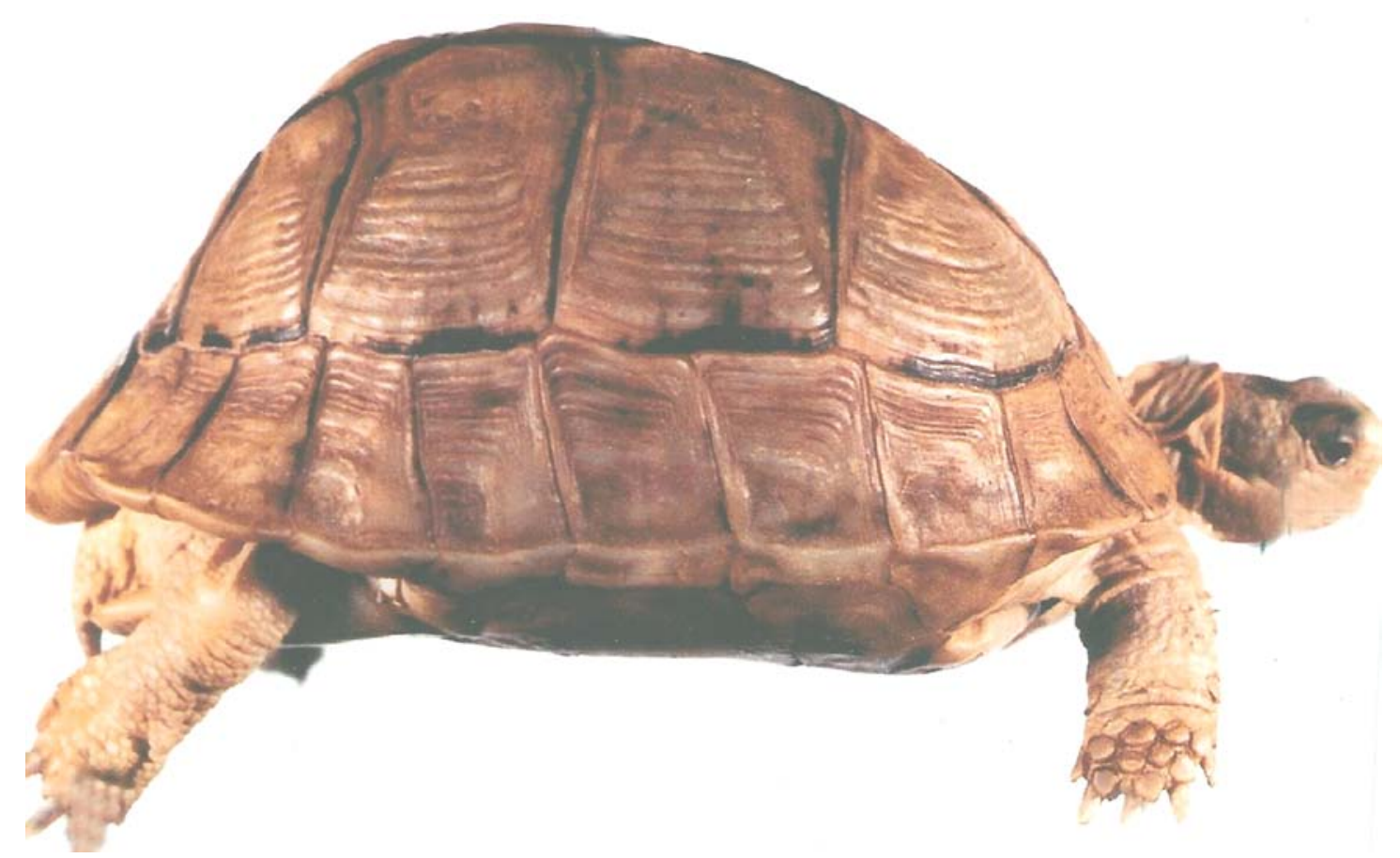

Fig. 1: Photograph of an adult; Testudo graeca terrestris

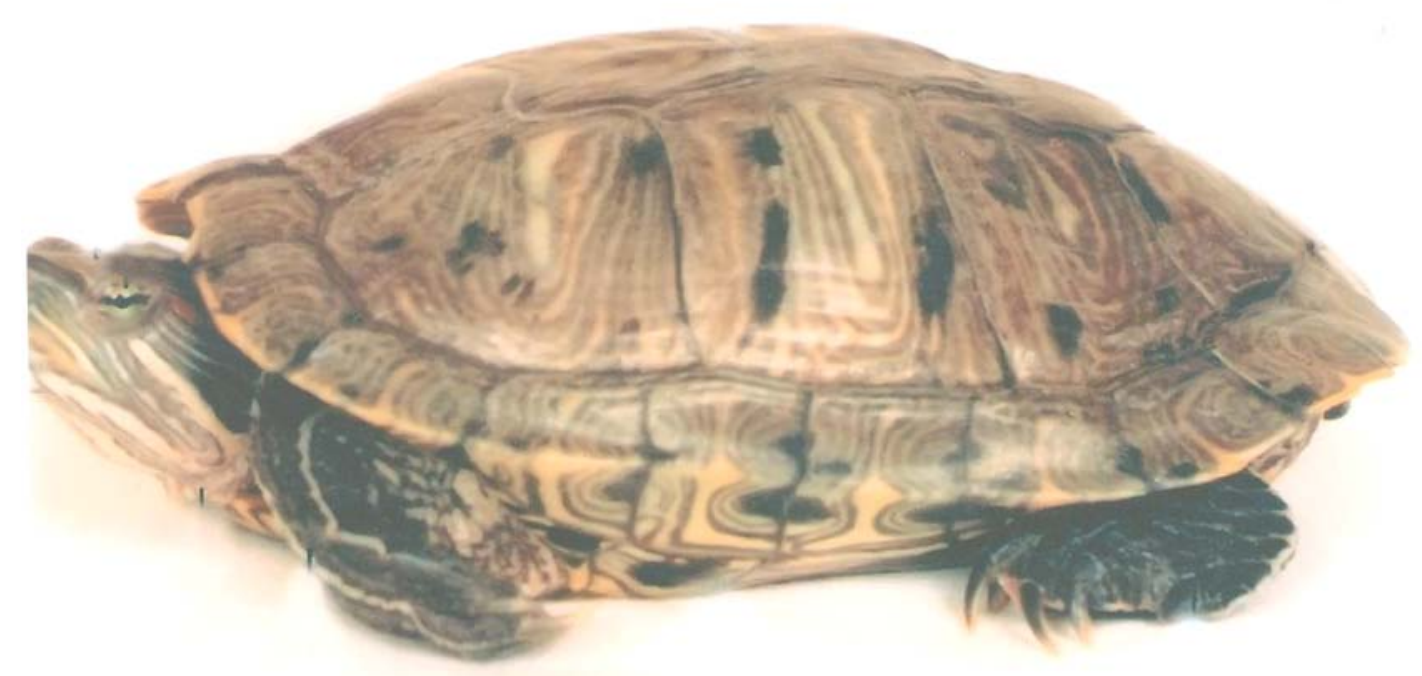

Fig. 2: Photograph of an adult; Pseudemys scripta elegans 


\section{ARABIC SUMMARY}

$$
\begin{aligned}
& \text { دراسات مورفولوجية وبيئية على نوعين من السلاحف } \\
& \text { سوزان عبد العزيز نجيب ـ رجاء محمود الديب ـ فاطمة كمال عبد الهادى ـ الهي } \\
& \text { قسم علم الحيوان - كلية العلوم - جامعة عين شمس الجس }
\end{aligned}
$$

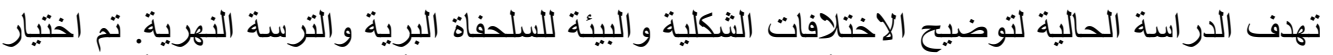

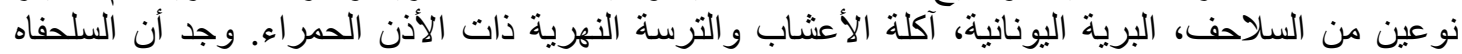

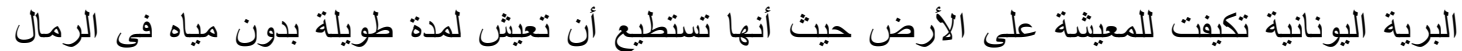

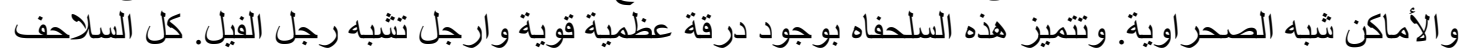

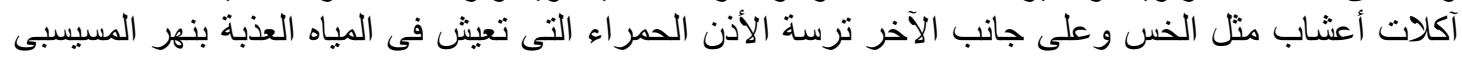

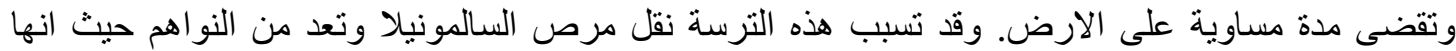

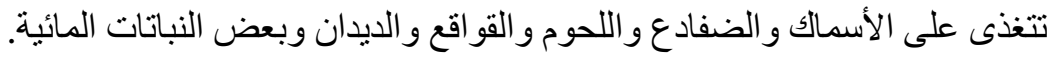

